\title{
To promote the Development of University Students' Innovative Education by Analyzing Teaching Management in Colleges and Universities
}

\author{
Hongyang Sun \\ School of Arts, East China University of Technology, China
}

Keywords: Colleges and universities; Teaching management; Innovative education; Development

\begin{abstract}
Innovative education has been vigorously advocated in recent years. Innovation not only helps individuals to make progress but also makes constant development for a country. In today's society with rapid development of science and technology, innovation has become a necessity for personal or social development. We should make constant innovations if we want to abide by social development. Thus, innovation should be put in an important position in higher education. During teaching management, colleges and universities should fully understand the deficiencies of innovative education, clarify the lacking institutional system as well as investigate college students' understanding of innovation. With knowledge of the aspects above, colleges and universities should also update their teaching management modes constantly so as to give full play to innovative education. Through constant exploration, a better teaching management mode which is suitable for the development of innovative education can be discovered with a sustainable development of high education. In this paper, it studies the development of innovative education promoted by teaching management in colleges and universities with detailed analysis so as to further propose some effective countermeasures.
\end{abstract}

\section{Introduction}

Colleges and universities are places where creative talents are cultivated, within which good educational modes are indispensable; while good management is also necessary, which are complementary of each other with a close relationship. During the development of innovative education, teaching management plays a decisive role in the results. The implementation purpose of teaching management can decide the development orientation of innovative education. The process is purposeful, organized and systematic, which is beneficial for the cultivation of innovative talents, and meanwhile it can help to promote a stable development for our country.

\section{The Concept of Teaching Management in Higher Institutions as Well as the Characteristics of Management}

The Concept of Teaching Management in Higher Institutions. Teaching management in higher institutions means that all educational activities should be conducted within a process from the formulation of educational goals to supervision of each educational section. The teaching management involves overall planning of teaching, teaching process as well as supervision of teaching quality and update of teaching mode and so on. By this way, all goals are connected to each other step by step which is good to ensure an effective teaching. Teaching management is the guarantee of teaching with a comprehensive effect.

The Characteristics of Teaching Management. Integrity. Teaching management is a systematic job consists of many aspects, including the determination of concepts, supervision of teaching, cognition of teaching achievements, establishment of teaching infrastructures as well as educational exploration and so on. In order to complete teaching management successfully, the administrators should have enough professional knowledge together with the spirit of keeping pace with the time. Guided by professional knowledge, administrators can manage to solve the problems finally with comprehensive analysis. Besides, they should constantly update the methods by coming 
up with new ideas. Regardless of the composition or the administrator, they all embody the feature of integrity, which is helpful for the further development of innovative education.

The Guiding Role. Teaching management defines the educational goals of higher institutions and plans its educational roads, which can not only defines the educational effect but also embodies the predictive effect of teaching management with certain guiding effect.

\section{Defects Existing in the Teaching Management of Higher Institutions}

The Management Items Haven't Been Prescribed Specifically. Before exploring the promotion effect of teaching management on innovative education in colleges and universities, we should first clarify the defects existing in teaching management. The first defect is that teaching management in higher institutions has no systematic, institutional and standard management document with a loose and free management. In recent years, various institutional constructions have been launched in our country, so colleges and universities surely need to appeal to national policies, during which many standard document for teaching management have been issued. However, the documents can't be implemented formally with effective role for their abstract features. Therefore, specific management document should be formulated by each college or university according to their own conditions so as to further carry out work.

Existing Problems about the Staff of Teaching Management in Higher Institutions. Experience in teaching management is accumulated in a long term, during which administrators can summarize various management problems they encounter with proposal of countermeasures to deal with emergencies. However, most administrators of teaching management in colleges and universities are lack of experience in management, and they do bad in summarizing management work as well as learning new management methods. Besides, they have inefficient communication with surrounding people. Thus, they may make some mistakes when dealing with difficult management so as to affect the working efficiency. Moreover, administrators of teaching management are required to possess certain innovative capability to carry out innovative education in higher institutions.

The System of Teaching Management in Higher Institutions Is Imperfect. Perfect teaching management system is the guarantee for a good quality and high efficiency of high education; however, imperfect teaching management system is a universal problem in most colleges and universities. The lack of institution can result in many problems which can't be solved earnestly. Thus, there will be many new problems occurring in daily work, which not only damages the working atmosphere, but also cause practical difficulties in cultivating talents with creativity.

\section{The Significance and Goals of Innovative Education in Higher Institutions}

The Significance of Implementing Innovative Education in Higher Institutions. Capability of innovation is an important part of personal comprehensive qualities as well as an important factor of national innovative development. Cultivation of college students' innovative capability refers to the infusion of innovative concepts in daily education so that students can learn methods and means of active study with more exploration on unknown science. As we all know, innovation is important for our society, and innovative education is an important means to cultivate innovative talents. Therefore, it is good to promote national comprehensive qualities and provide basic guarantee for national vigorous development by strengthening the implementation of innovative education.

The Goals of Innovative Education. The innovative spirit should be aroused with encouragement of innovative consciousness

Active awareness is useful for guiding college students' behaviors, so the prior goal to cultivate college students' innovative capability is to enhance their innovative awareness and innovative spirit. It is not easy for them to adopt new ideas since the traditional educational way as well as learning methods have been deeply implanted in this mind. Thus, higher institutions should run through innovative concept into each section of daily teaching to create a wide atmosphere for their innovative study. Under this circumstance, students' self innovative awareness can be actively 
strengthened. That is, their imagination can be set free with their own unique potentials in future study.

Cultivation of Innovative Thoughts. With active innovative awareness, students need to possess innovative thoughts. The innovative thoughts are not born with, but they are accumulated and formed in the long-term constant practice. With distinctive characteristic and revolution as its goals, innovative thought manifests in special, quick and smooth thinking and so on. Cultivation of such though is not only beneficial to students' self development, but it can also make major contributions to national construction.

Cultivation of Innovative Talents. The final goal of innovative education is $t$ cultivate innovative talents. First, the key of talent cultivation is teacher, so higher institutions should be strict with the recruitment of teachers so as to ensure the high quality of teaching staff. Thus innovative teaching can be further ensured with high success rate of innovative teaching. During the teaching, colleges and universities should always put students in the first place and all teaching goals should surround the cultivation of innovative talents. Meanwhile, all plannings of innovative education should be made for students with all achievements shared by students together. Effective suggestions proposed by college students should be adopted to fully embody their values. In the harmonious teaching environment, we can surely cultivate innovative talents with capabilities.

\section{Effective Countermeasures Need to Be Adopted During the Development of Innovative Higher Education.}

\section{The Teaching Reform of Innovative Education Should Be Deepened}

The Cultivation System of Innovative Talents Should Be Perfected By Deepening the Teaching Reform of Innovative Education. In recent years, in order to appeal to national policies and the development need of times, higher institutions have constantly formulated their own systems during teaching management to protect their advantages. As for the management of innovative education, colleges and universities should carry out reformation boldly to perfect the cultivation system of innovative talents. First, rules should be formulated during the implementation. Some systems directly related to students' graduation such as full credit system and AB credit system should be formulated to standardize their behaviors. With certain standards, the overall goal of higher education can be realized to finish the popularity and promotion of innovative education. One of the most important points for innovative education is to display one's personality. Therefore, while realizing the common goals, schools should help to develop students' own potentials specifically with special teaching methods by students' individuality. Meanwhile, innovative education as well as scientific and innovative activities should be included into students' study plans by colleges. Besides, teaching staff should implement the teaching concepts for cultivation of innovative talents comprehensively by changing their previous thoughts. During the development, higher institutions are expected to form an innovative educational system with the promotion of scientific and technological innovation as the core, and cultivation of innovative talents with sound comprehensive qualities as the purpose.

The Teaching Concepts Should Be Updated by Implementing the Cultivation of College Students' Innovative Capability to Class. For Besides self study, most knowledge is obtained in class college students. That is to say, class is still the main battlefield for students' study. When cultivating students' innovative capabilities, class education should be given great importance by running scientific and technological innovation through each section of class teaching. Environment is especially important for students to receive a new idea, so cultivation of students' innovative capability relies on the assistance of class teaching and activity as well as long-term training of innovative thoughts in class. During the teaching management of higher institutions, innovative education should be applied to both public class and compulsory class to complete the teaching. In terms of teaching contents and forms, corresponding changes should be made by adding flexible modes of modern teaching to traditional educational modes. For example, teaching contents of innovative education can be taught in the form of lectures so that students can remember the knowledge more easily. Beside, concepts should be combined with practice so that students can 
better understand them with stimulation of interest, which requires teachers to implement certain innovative practice to enhance students' mastery of innovative knowledge. By the update of educational and teaching concepts, students' innovative capabilities can be improved with a promotion of innovative education.

Cultivation of Teaching Staff with Innovative and Pioneer Spirits. Teachers play an important role in teaching knowledge and enlightening study, so it is important for colleges and universities to promote current teachers' teaching abilities if they want to cultivate talents with innovative capabilities. Besides, teachers are major participants of various scientific research activities in higher institutions, so their opinions are valuable fortunes for students; and meanwhile they help to cultivate more talents for the country and inherit science and technology. Thus, the role of teachers should be given into full play by establishing tutorial system for college students' scientific and innovative activities, which can select excellent teachers with high quality gradually so as to establish a powerful guiding team of scientific and research teachers. In addition, assessment system should be formed accordingly to evaluate teachers' teaching level irregularly to ensure enough innovative capability and full innovative spirit. During the assessment, teachers with good performance should be given certain encouragement and material rewards to enhance their teaching abilities, and thus they can finally become the leaders of innovative education.

Teaching Level of Innovative Education can Be Improved by Carrying out Standard Construction in Higher Institutions. Addressing the problems existing in current teaching management, colleges and universities can choose to adjust the teaching management contents in their schools. That is, standardization can be conducted for the construction in higher institutions to solve the defects. Implementation of innovative education in higher institutions is not a simple job, which needs to be coordinated by varies parties in the school. Only if the teaching management is conducted smoothly that other work can be done successfully. Therefore, colleges and universities should improve the working level of their management teams with a series of unified training on their administrators to strengthen their management abilities; besides, administrators should enhance communication with each other to discover existing problems to realize management standardization.

To Perfect the Feedback Mechanism. In order to ensure the operation efficiency and development of innovative education, the feedback mechanism should be perfected during teaching management so that teaching staff in higher institutions can be well supervised with better service attitude, teaching responsibilities and strong self-constraint. Under this management, teachers' teaching level can be effectively promoted with better quality of innovative education.

\section{Conclusion}

The constant update of teaching management mode is to appeal to the development need of higher institutions, which is a challenging job. In a word, to promote innovative education, teaching management mode should be themed as innovation with students as the center. The innovative education can only be popular with scientifically planned roads.

\section{References}

[1] Kang Zaimin, Guo Jianying. Discussion on the Promotion of Teaching Management on the Development of College Innovative Education [J]. Art, Science and Technology. 2015,07:270.

[2] Duan Chengfang. Reform of Teaching Management to Cultivate College Students' Innovative Capability[D]. Hunan University of Agriculture, 2005.

[3] Zhang Wenhxue. Study on the Institutionalization of College Students' Ideological and Political Education[D]. China University of Geosciences. 2012

[4] Zhang Xuefei. Study on the Teaching Effectiveness of Ideological and Political Theories in Colleges[D]. Liaoning Normal University, 2011. 
[5] Kong Xiameng. Study on the Course of College Career Education[D]. Southwest University, 2013.

[6] Wang Xiaohui, Study on the Individualized Talent Cultivation Mode in Top Universities[D]. Central China Normal University, 2014.

[7] Shi Yangling. Study on the Development Status and Cultivation of College Students' Innovative Capabilities in China[D]. Anhui University, 2014.

[8] Zheng Hong. Study on People-Oriented Teaching Management in Colleges[D]. Shandong University, 2008. 